\title{
Modelling Humus Reserves with Livestock Wastes Application
}

\author{
Tingayev Anatoly Vladimirovich \\ Altai State Agricultural University \\ Barnaul, Russia \\ e-mail: avtin@asau.ru
}

\author{
Davydov Aleksandr Stepanovich \\ Altai State Agricultural University \\ Barnaul, Russia \\ e-mail:agau@asau.ru
}

\begin{abstract}
Application of livestock wastes during three years has exerted generally positive influence on humus storage. Pig effluents application assisted in storing the total forms of nutrient elements in comparison to the bench-mark data and control. The more significant storage of nutrient elements in soil and certain increase of organic matter content has been witnessed during the increase of the rate of livestock wastes application from 100 to 300 m3/ ha.

A mathematical model reflecting the dynamics of humus reserve by means of livestock waste and plant residues humification and considering humus waste has been developed. The adequacy of the model was analyzed with regards to the data obtained as a result of watering with pig effluents in the meadowsteppe area of Togulsky region in Altai Krai, Russia. The mathematical model has gained high evaluation of approximation accuracy. The approximation error is $6 \%$.

The estimate of annual irrigation by pig effluents during 20 years at the rate of wastes equal to $300 \mathrm{~m} 3 / \mathrm{ha}$ has indicated the 1.21 times increase of humus reserve from $146.858 \mathrm{ton} / \mathrm{ha}$ to 177.87 ton/ha; while the content of non-humified organic matter will increase during 7 years in soil up to 1.19 ton/ha and then the content will stabilize.

The 20 year forecast with the irrigation with pig effluents with the norm $300 \mathrm{~m} 3 / \mathrm{ha}$ has shown the negligible storage of nonhumified organic matter of pig effluents in soil.
\end{abstract}

Keywords—humus, pig effluents, soil, irrigation, mathematical model.

\section{INTRODUCTION}

Being irrigated with livestock waste, soil is enriched with organic material, micro- and macro-elements, improves its hydrophysical properties.

It is necessary to prepare the wastes thoroughly, rigidly observe the irrigation operating condition, hold activities on reinforcing the content of biogenic substances in active layer and their more active use by plants in order to prevent environment pollution. Irrigation with livestock waste by stock breeding complexes leads to the following tasks solution: livestock wastes utilization, irrigated farmland expansion and the soil fertility increase, crop productivity and feed crop quality. It is vital to determine the maximum permissible level of pig effluents application. It depends on the soil fertility, properties and chemical makeup of pig effluents as well as other factors.
It is necessary to apply mathematic modeling in order to assess the impact of pig effluents on the content of organic matter in soil.

\section{II.OBJECTS, CONDITIONS AND RESEARCH METHODS}

In the world, there are a lot of models which show the alteration of organic matter in soil [1-11]. These models do not take into account the storage of livestock waste organic matter not subjected to humification, which prevents the justification of the periodicity and norm of irrigation with livestock waste.

There was developed a mathematical model [12], the first differential equation of which demonstrates the dynamics of humus storage by means of humification of livestock wastes and plants residues organic matter, and registers the humus losses. Other equations do not register the changes in the content of organic matter and plants residues not subjected to decay and contained in soil.

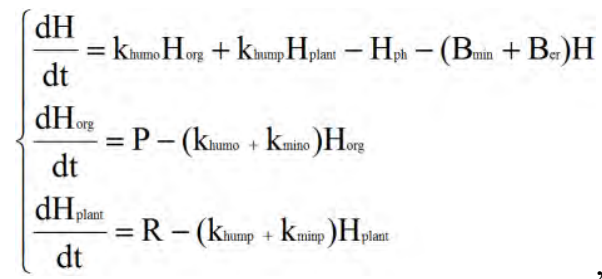

where $\mathrm{H}$ is humus reserve in soil, ton/ha; $\mathrm{H}_{\text {org }}$ is organic matter of livestock wastes (not subjected to decay) into soil, ton/ha; $\mathrm{H}_{\text {plant }}$ is organic matter of plant residues (not subjected to decay) into soil, ton/ha; $\mathrm{k}_{\text {humo }}$ is the isohumus coefficient of livestock waste, year ${ }^{-1} ; \mathrm{k}_{\text {mino }}$ is the mineralization coefficient of livestock waste, year ${ }^{-1}$; $\mathrm{P}$ is the norm of livestock waste application, ton/ha per year; $k_{\text {hump }}$ is the coefficient of plants residues humification, year ${ }^{-1} ; \mathrm{k}_{\text {minp }}$ is the coefficient of plants residues mineralization, year ${ }^{-1} ; \mathrm{R}$ is the output of plants residues organic matter, ton/ha per year; $\mathrm{B}_{\min }$ is the coefficient of humus mineralization, over the period; $B_{\text {er }}$ is the coefficient of losses caused by erosion, over the period; $\mathrm{H}_{\mathrm{ph}}$ is the physical humus losses, ton/ha per year.

$\mathrm{H}_{\mathrm{ph}}$ can be assessed by its content in soil solution, where humus' most active part moves in the form of fulvic acid [7]:

$$
\mathrm{H}_{\mathrm{ph}}=0.01 \mathrm{HC}_{\mathrm{h}}, \text { ton/(ha per year), }
$$


where $\mathrm{H}$ is annual soil washability, $\mathrm{mm} ; \mathrm{C}_{\mathrm{h}}$ is humus solubility, $\mathrm{kg} / \mathrm{m}^{3}$.

The coefficient "B" registers the humus decay and mineralization $\left(\mathrm{B}_{\min }\right)$, and its losses caused by erosion $\left(\mathrm{B}_{\mathrm{er}}\right)[6]$ :

$$
\mathrm{B}=\mathrm{B}_{\min }+\mathrm{B}_{\mathrm{er}} \text {, year }{ }^{-1}
$$

The coefficient of humus mineralization on agricultural land depends on the soil type.

The coefficient $B_{\text {er }}$ is connected with the erosion force [8]:

$$
\mathrm{B}_{\mathrm{er}}=0,0001 \mathrm{~W}_{\mathrm{er}} /(\gamma \mathrm{h}) \text {, }
$$

where $\mathrm{W}$ is the mass of the removed soil, ton/ha per year; $\gamma$ is soil density, ton $/ \mathrm{m} 3 ; \mathrm{h}$ is the layer of the removed soil, $\mathrm{m}$. According to Golovanov A.I., the coefficient $B_{\text {er }}$ for slightly erodible soils is equal to 0.00125 year $^{-1}$, for moderately erodible soils is equal to 0.00417 year $^{-1}$, for intensely erodible soils is equal to 0.00833 year $^{-1}$.

The adequacy of the model was checked on the basis of data obtained as a result of watering by pig effluents in the meadowsteppe area of Togulsky region in Altai Krai, Russia [15].

The soils are majorly the chernozem leached with the content of nitrogen equal to 0.415 , phosphorus -0.204 , kalium $-2.6 \%$. The soil density in the upper layer is $1.16 \mathrm{gr} / \mathrm{cm}^{3}$, the soil space is more than $50 \%$.

The amount of precipitation in the meadow-steppe area of Togulsky region is $290 \mathrm{~mm}$ annually, including $284 \mathrm{~mm}$ during the vegetation period. The total precipitation over the period characterized by the temperature higher than $+50 \mathrm{~F}$ is $225-250$ $\mathrm{mm}$.

The field studies have been conducted on the basis of the pig-breeding farm "Antipinskiy" during 3 years in 3-field fodder crop rotation, including the following croppers: oats, wheat, peas. The mentioned croppers were chosen to be included into the crop rotation according to several reasons. Small grain and pulse crops for feed conveyor should be the predominant for the farms specializing in pig growing and feeding with regards to the cropping pattern. Their growth alongside the application of pig effluents is allowed according to sanitary and veterinary requirements.

The major drawbacks of these croppers selection is the enlargement of irrigation area by $30-40 \%$ due to low removal of biogenic elements by crops. However, the positive effect of it is a significant decrease of pig effluents into soil.

The field study includes 4 variations different in the norms of the applied livestock wastes (scheme):

1) Control (without wastes application);

2) Application of pig effluents in the norm $100 \mathrm{~m} 3 / \mathrm{ha}$;

3) Application of pig effluents in the norm $200 \mathrm{~m} 3 / \mathrm{ha}$;

4) Application of pig effluents in the norm $300 \mathrm{~m} 3 / \mathrm{ha}$.

The studies applied agrotechnics utilized on the farm. The secondary tillage included under-winter ploughing after harvesting the forecrop and harrowing with cultivating in spring. The recognized variety of wheat "Altayskaya - 92" was used in the research. The plot area comprised $50 \mathrm{~m}^{2}$, registration plot comprised $32 \mathrm{~m}^{2}$.

Fertilizing irrigation was implemented within the period of tillering and stems elongation of small grain crops and branching of peas.

The field study was organized and implemented according to the experimentation technique.

The utilized waste of the pig-breeding farm "Antipinskiy" has $90.74 \%$ of the waste fractions about less than $0.25 \mathrm{~mm}$ (the size of fractions not impeding the operation of sprinkling machinery) and $9.26 \%$ of the factions larger than $0.25 \mathrm{~mm}$.

If the annual output of waste is $150,000 \mathrm{~m}^{3}$, the amount of the fractions larger than $0.25 \mathrm{~mm}$ will be equal to 13890 tons. These solid fractions must be removed. A separation plant being waste strainer able to separate the fractions larger than $0.25 \mathrm{~mm}$ is used for this objective. In general the quality of the prepared pig effluents meets the engineering and landreclamation requirements to irrigation machines operation. Wastes are rich in organic and nutrient elements essential for plants. They were annually checked with the aim to determine the content of waste.

The utilized pig effluents have a medium salt load with the dry extract concentration of dissolved solids at an average of $4006 \mathrm{mg} / \mathrm{l}$. Pig effluents reaction is faintly-acid, $\mathrm{pH}$ is 6.6 while the content of nitrogen is 744 , phosphorus is 532 , kalium is 843 $\mathrm{mg} / \mathrm{l}$. Irrigational coefficient of Stebler is 6.1 at an average, which characterizes the effluents as satisfactory. The data on sodium adsorption ration (SAR) and rectified SAR denote that the effluents are suitable enough because they do not cause soil alkalization.

Effluents' suitability for being applied on agricultural lands is measured according to irrigation criteria. In accordance with agricultural-irrigation estimate the effluents of the pig-breeding farm "Antipinskiy" are generally favourable to be used as fertilizer irrigation.

Irrigational coefficient of Stebler is 6.1 at an average, which characterizes effluents as satisfactory.

The data on SAR and rectified SAR state that the effluents are suitable for irrigation because they do not cause alkalization of soil.

The effluents of the pig-breeding farm "Antipinskiy" have been defecated when brought to farm fields during three years. Their sanitary-and-bacteriologic estimate testifies that they contain the permissible quantity of nonpathogenic microorganisms (coli-forms, fecal coliforms, enterococci, clostridiums) and do not contain pathogenic flora and helmint ovules.

It is stipulated by the treatment of livestock wastes coming for utilization. However, the selected samples contain high quantity of lactose and positive E coli.

The study of livestock waste from holding basin (conducted before the irrigation) indicated the presence of eelworm and whipworm ovules, which denotes the disposal of sanitary sewage into dung effluents. Eelworm ovules were found in the 
blank samples taken before the irrigation, which indicates that dehelminthization on certain fields areas in winter was not complete. However, the eelworm ovules had not been found in the unit connections by the time of check material sampling (after all types of irrigation).

Satisfactory sanitary-and-bacteriologic of livestock wastes is completed by the analysis of heavy metals content whose content restricts the application of wastes for agricultural crops irrigation with the existing maximum acceptable concentration. The obtained data enables to conclude that the livestock wastes used in our research for fertilizing and moistening contain a certain amount of heavy metal. Thus, the average cooper content in wastes was equal to $0.002 \mathrm{mg} / \mathrm{l}$ at the maximum allowable concentration $1.0 \mathrm{mg} / \mathrm{l}$, zink $-0.001 \mathrm{mg} / \mathrm{l}$, which is 1000 times less than maximum allowable concentration, cobalt $-0.0002 \mathrm{mg} / \mathrm{l}$ at the maximum allowable concentration 1.0 $\mathrm{mg} / \mathrm{l}$, cadmium $-0.001 \mathrm{mg} / \mathrm{l}$, which is 1000 times less than maximum allowable concentration. The largest concentration of heavy metals found in wastes was represented by copper and zink, and selenium was the closest to the maximum allowable concentration (2.5 times lower than maximum allowable concentration).

\section{RESEARCH RESULTS}

Fertilizing irrigation implemented by the pig-breeding farm "Antipinskiy" has produces the positive effect on the main agrochemical properties of leached chernozem. The most notable accumulation of nutrients in the soil and a certain increase of organic matter can be seen with the livestock wastes norm augmentation from 100 to $300 \mathrm{~m}^{3} /$ ha. Thus, humus concentration in the soil layer of $0-20 \mathrm{~cm}$ has increased from 6.33 to $6.51 \%$ and in the soil layer $0-60 \mathrm{~cm}$ - from 4.54 to $4.71 \%$ as compared to the bench-mark data in the three years with the norm $200 \mathrm{~m}^{3} /$ ha. Thus, humus concentration in the soil layer of $0-20 \mathrm{~cm}$ has increased from 6.33 to $6.52 \%$ and in the soil layer $0-60 \mathrm{~cm}$ - from 4.54 to $4.74 \%$ as compared to the bench-mark data in the three years with the norm $300 \mathrm{~m}^{3} / \mathrm{ha}$. These norms were smaller with the wastes norm $100 \mathrm{~m}^{3} /$ ha and they increased up to 6.48 and $4.67 \%$.

All three experiment variations demonstrated comparatively rapid decrease of humus with depth, while the most remarkable decrease started from the depth of $40-60 \mathrm{~cm}$. In general, the distribution of humus over the soil crossover was stable both with control and wastes applications.

Thus, the application livestock waste during three years has had a positive impact on humus storage. The storage of the nutrient elements total form in comparison with the bench-mark data and control was noted with livestock waste application.

A mathematical model being given a high estimate of approximation accuracy was used for the further forecasting of change in humus reserves under the influence of pig effluents. The approximation error is $6 \%$.

Humus reserves modeling was made with the application of software, which enabled to make calculations of the irrigation with pig effluents.
The forecast of irrigation with pig effluents for 20 years with the norm of wastes equal to $100 \mathrm{~m}^{3} /$ ha has shown the 1.12 times increase of humus reserves from 146.858 ton/ha to 164 ton/ha, with the norm $200 \mathrm{~m}^{3} / \mathrm{ha}-1.16$ times increase from 146.858 ton/ha to 171 ton/ha, with the norm $300 \mathrm{~m}^{3} / \mathrm{ha}-1.21$ times increase from 146.858 ton/ha to 177.87 ton/ha.

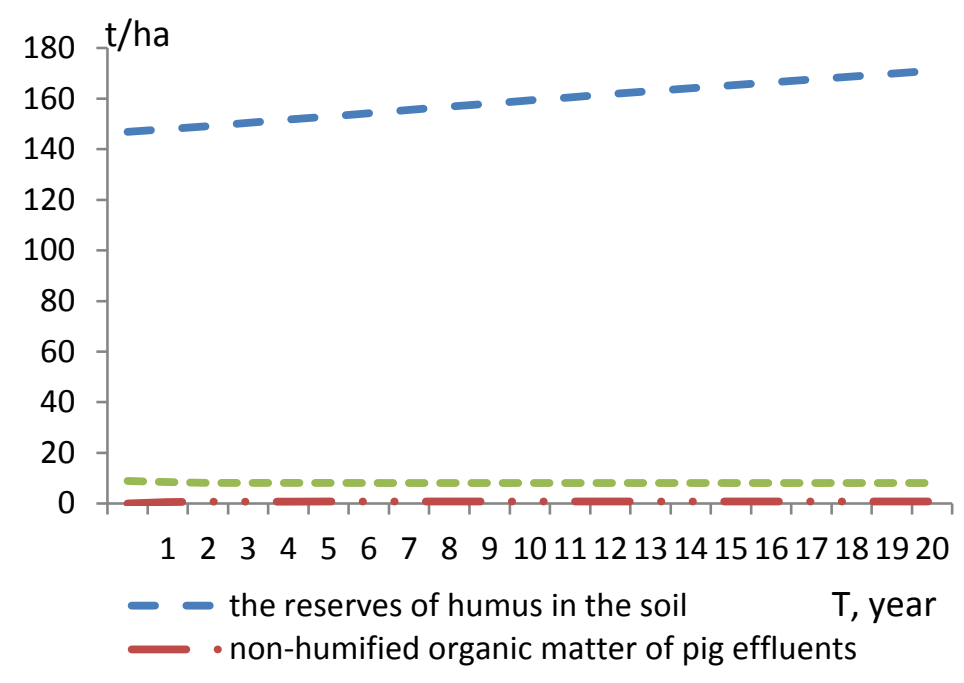

Fig 1 Forecast of humus reserve in Togulsky region at of irrigation with pig effluents during 20 years with the norm $200 \mathrm{~m}^{3} /$ ha.

The concentration of humified organic matter of livestock wastes with the norm $200 \mathrm{~m}^{3} /$ ha during 6 years will grow to 0.79 ton/ha, then it will stabilize; with the norm $300 \mathrm{~m}^{3} /$ ha during 7 years it will increase up to 1.19 ton/ha, then it will stabilize.

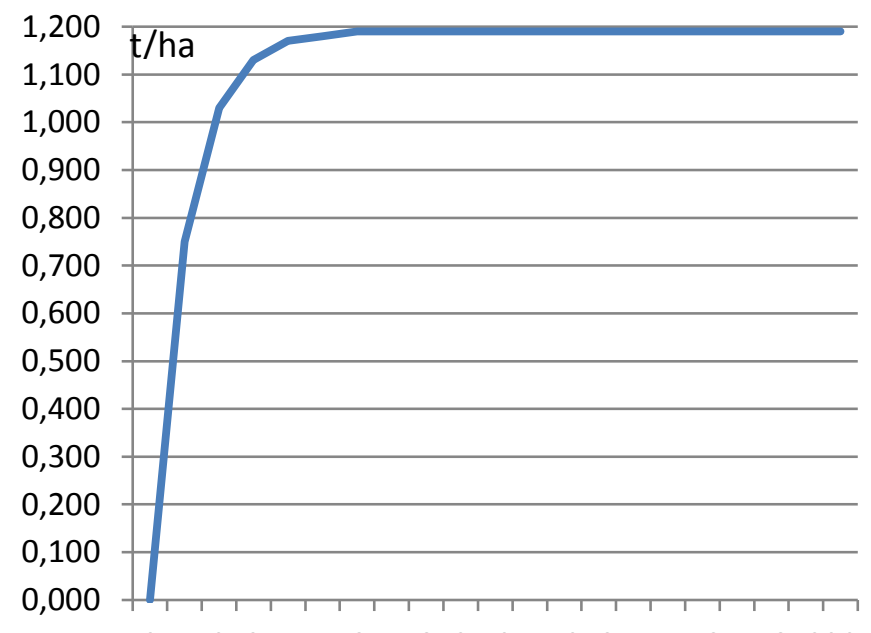

01234567891011121314151617181920

Fig. 2 Forecast of humus reserve in Togulsky region at of irrigation with pig effluents during 20 years with the norm $300 \mathrm{~m}^{3} / \mathrm{ha}$.

The consentration of humified organic matter of livestock wastes in the soil under the conditions of long-term irrigation will not contaminate the Togulsky region soil. 


\section{CONCLUSION}

The differential characteristic of the model is accounting the storage of organic matters in the soil alongside humification processes. The model enables to justify the norm and periodicity of irrigation with pig effluents with the objective not to deteriorate the soil properties and not to cause ground-water contamination.

The forecast of the irrigation with pig effluents during 20 years has proved to be essential for humus reserve in the Togulsky region soil and insignificant reserve of non-humified organic matter of the pig effluents.

\section{References}

[1] L. Moklyachuk, I. Yatsuk, O. Mokliachuk, L. Plaksiuk. "Mathematical modeling as a tool for determination of tendencies in changes of humus concentration in soil of arable lands", Emirates Journal of Food and Agriculture, Vol. 28, no. 6, Nov. 2017, pp. 438-4, doi:https://doi.org/10.9755/ejfa.2016-04-348.

[2] I. G. Malkina-Pykh, Y. A. Pykh, "HUMOD - the model of soil organic matter dynamics in the natural and land-used ecosystems", Advances in Ecological Sciences,vol. 1, 1998, pp. 405-416.

[3] V. F. Drichko, L. G. Bakina, N. E. Orlova, "Stable and labile components of humus in soddy-podzolic soils", Eurasian Soil Science, vol. 46, No. 1, 2013, pp. 37-43, doi:10.1134/S1064229312110038.

[4] M. A. Nadporozhskaya, P.Čudlin, F. Novak, S. S. Bykhovets, O. G Chertov, A. S. Komarov, A. V. Mikhailov, "Analysis of the soil organic matter stability in spruce forests of krkonose in czechia on the basis of the ROMUL mathematical model", Eurasian Soil Science, vol. 42, No.6, 2009, pp. 657-667, doi:10.1134/S1064229309060118.

[5] D. Di Chio, D. Potenz, E. Righetti, "Test of a mathematical model for degradation kinetics of components of cultivated soil. its use to determine optimal nutrient dosage required to maintain stable soil conditions", Bioresource Technology, vol. 74, No. 3, 2000, pp. 249-255, doi:10.1016/S0960-8524(00)00014-6.

[6] A.D. Balaev, L.R. Petrenko, "Conceptual models of humus mill chornozemiv", Bulletin of Agrarian Science, 1999, No. 4, pp. 10-14.

[7] S. Manzoni, G. Piñeiro, R.B. Jackson, "Analytical models of soil and litter decomposition: Solutions for mass loss and time-dependent decay rates", Soil Biology\&Biochemistry, 2012, No. 50, pp.66-76.

[8] C.A. Sierra, M. Muller, S. E. Trumbore, "Models of soil organic matter decomposition: the SOILR package,version 1.0", Geoscientific Model Development, 2012, Retrivied from: http://www.geosci-modeldev.net/5/1045/2012/gmd-5-1045-2012.pdf.

[9] N.I. Gaydash, "Algorithm for calculating the balance of humus in a field crop rotation", Bulletin of the Russian Academy of Agricultural Sciences, 2001, Np. 4, pp. 86-87.

[10] A.I. Golovanov, "Environmental Engineering", Moscow: Kolos, 2007, p. 551.

[11] Yu.P. Sukhanovsky, S.I. Sanzharova, A.V. Pruschik, "Modeling of humus dynamics in erodible black soil", 2010, Kursk: Geo-network of the Institute of Agrochemistry named after D.N. Pryanishnikov, Retrieved from: http://www.geo-set.ru/data/files/suhanovskiy rus.pdf.

[12] A.V. Tingaev, "Mathematical modeling of humus reserves in the soil when using organic waste", Bulletin of the Altai State Agrarian University, 2014, vol. 122, No. 12, pp. 60-64.

[13] J. Lose, K. Mathieu, "Explanatory Dictionary of Soil Science", Moscow: Mir, 1998, p. 398

[14] V.A. Vasiliev, "Organic fertilizers in intensive farming", Moscow: Kolos, 1984, p. 303.

[15] R.P. Vorobieva, A.S. Davydov, "The effectiveness of the use of waste in the conditions of agrocenoses of the south of Western Siberia", Bulletin of the Barnaul State Pedagogical University, 2002, vol. 329, p. 329. 